Alcohol Prices, Consumption, and Traffic Fatalities

Author(s): Douglas J. Young and Agnieszka Bielinska-Kwapisz

Source: Southern Economic Journal, Vol. 72, No. 3 (Jan., 2006), pp. 690-703

Published by: Southern Economic Association

Stable URL: http://www.jstor.org/stable/20111841

Accessed: 10/06/2014 13:52

Your use of the JSTOR archive indicates your acceptance of the Terms \& Conditions of Use, available at http://www.jstor.org/page/info/about/policies/terms.jsp

JSTOR is a not-for-profit service that helps scholars, researchers, and students discover, use, and build upon a wide range of content in a trusted digital archive. We use information technology and tools to increase productivity and facilitate new forms of scholarship. For more information about JSTOR, please contact support@jstor.org. 


\title{
Alcohol Prices, Consumption, and Traffic Fatalities
}

\author{
Douglas J. Young* and Agnieszka Bielinska-Kwapisz†
}

\begin{abstract}
We examine the relationships among alcohol prices, consumption, and traffic fatalities using data across U.S. states from 1982 to 2000 . Some previous studies have found large, negative associations between alcohol taxes and fatalities. However, commonly used price data suggest little or no connection between alcohol prices and fatalities. These apparently conflicting findings may result from measurement error and/or endogeneity in the price data, which biases ordinary least squares estimators toward a finding of no price effects. Using alcohol taxes as instrumental variables, fatalities are found to be negatively related to prices. In addition, alcohol consumption is strongly positively related to fatalities. However, biases may still remain, because taxes are not entirely suitable as instruments.
\end{abstract}

\section{JEL Classification: I1, H2, C3}

\section{Introduction}

Traffic fatalities are a leading cause of premature death, particularly among people under 35 years of age. ${ }^{1}$ Alcohol is involved in about $40 \%$ of all traffic fatalities, and hence alcohol policies have the potential to significantly reduce fatality rates. ${ }^{2}$

This paper focuses on the links between alcohol prices, consumption, and traffic fatalities. The fundamental question is, How does the price of alcohol affect fatalities? Price is an important policy variable, since it is affected by taxes and other measures, and for some beverages in some states, price is actually set by alcohol control authorities. Economic theory predicts that alcohol consumption will be negatively related to price, and thus increases in price are expected, ceteris paribus, to reduce fatalities. Schematically, the hypothesized relationships are Tax $\rightarrow$ Price $\rightarrow$ Consumption $\rightarrow$ Fatalities.

Although there is little dispute about the qualitative nature of these relationships, there is a wide range of quantitative estimates of the magnitudes involved at each step and a further question about whether, taken together, the estimated magnitudes make sense. Some researchers, for example, have estimated reduced form relationships based on tax and fatality data, ignoring the intermediate relationships between taxes and prices, prices and consumption, and consumption and fatalities. Even these

* Department of Agricultural Economics and Economics, 208A Linfield Hall, Montana State University, Bozeman, MT 59717-0292 USA; E-mail djyoung@montana.edu; corresponding author.

$\dagger$ College of Business, Montana State University, Bozeman, MT 59717-3040 USA.

This research was supported by the National Institute on Alcohol Abuse and Alcoholism under grant R03 AA13264. Helpful remarks were provided by Jon Nelson, two anonymous reviewers, and co-editor Dek Terrell. All conclusions and any errors are the sole responsibility of the authors.

Received June 2004; accepted March 2005.

${ }^{1}$ See http://www.cdc.gov/nchs/data/nvsr/nvsr49/nvsr49_08.pdf, Table 10.

${ }^{2}$ Based on estimates from the National Highway Traffic Safety Administration, http://www-nrd.nhtsa.dot.gov/pdf/nrd-30/ NCSA/TSFAnn/TSF2003EarlyEdition.pdf. Estimates from the National Institute on Alcohol Abuse and Alcoholism are lower: http://www.niaaa.nih.gov/databases/crash01.txt. 
studies have produced markedly different estimates. ${ }^{3}$ There are relatively few studies taking a structural approach. Young and Bielinska-Kwapisz (2002) find that beverage prices rise more than one for one with alcohol taxes, suggesting that taxes may indeed have substantial impacts on consumption and fatalities. However, the few studies that estimated a price-fatality relationship yielded inconsistent results. ${ }^{4}$

A key empirical concern is the quality of the price data that is typically employed in analyses of consumption, fatalities, and other behaviors. Many studies have employed beer, wine, and spirits prices collected by the American Chamber of Commerce Researchers Association (ACCRA), but these data are likely to suffer from substantial measurement error (Young and Bielinska-Kwapisz 2003). ${ }^{5}$ In addition, beverage prices may be endogenous in the sense that higher demand may result in higher market prices (Manning, Blumberg, and Moulton 1995).

Measurement error in the price data implies that the ordinary least squares (OLS) estimator is biased and inconsistent. Similarly, endogeneity of prices also renders the OLS estimator biased and inconsistent. In simple models, both problems bias the estimated price elasticity toward zero. That is, OLS may substantially underestimate how much higher prices discourage consumption and traffic fatalities.

However, alcohol taxes-including beer, wine, and spirits per unit excise taxes, percentage excise taxes, and state markups in control states-provides a set of instrumental variables that, in principle, can resolve the problems with the price data. This paper applies instrumental variable (IV) techniques to the estimation of the price-fatalities and consumption-fatalities linkages. The results provide substantial evidence of measurement error and/or endogeneity in both the price and consumption data, and IV estimates of price and consumption effects on fatalities are substantially larger and more significant than those from OLS. However, a priori considerations and some evidence suggest that taxes are not fully suitable as instruments.

\section{Methods}

We estimate regression models that express fatality rates as functions of alcohol prices (or consumption), socioeconomic characteristics, the legal environment, and state and year fixed effects:

$$
y_{i t}=\ln P_{i t} \alpha+x_{i t} \beta+u_{i}+v_{t}+w_{i t} .
$$

The dependent variable, $y_{i t}$, is the logistic transformation of the observed fatality rate, $r_{i t}$, that is fatalities per capita. The logistic transformation restricts the predicted value of fatalities to be nonnegative and has been widely used in previous studies. ${ }^{6}$ However, the logistic transformation implies that the disturbance $w_{i t}$ is heteroskedastic, and thus Equation 1 is estimated by weighted least squares (Greene 2003, section 21.4.6).

\footnotetext{
${ }^{3}$ For examples, Cook (1981); Chaloupka, Saffer, and Grossman (1993); and Ruhm (1996) find large, negative relationships between beer taxes and fatalities, whereas Dee (1999); Mast, Benson, and Rasmussen (1999); and Young and Likens (2000) find little or no relationship.

${ }^{4}$ Sloan, Reilly, and Schenzler (1994) find that alcohol price is negative and significant at the $10 \%$ level in one of three specifications, but that it is sensitive to the inclusion of time-fixed effects. Price effects in Young and Likens (2000) are small, negative, and statistically insignificant.

${ }^{5}$ The ACCRA data have been used in studies of alcohol consumption by Gruenewald, Ponicki, and Holder (1993); Kenkel (1993); Manning, Blumberg, and Moulton (1995); Beard, Gant, and Saba (1997); Grossman, Chaloupka, and Sirtalan (1998); and Nelson (2003); studies of traffic accidents, homicides, suicides, and other deaths by Sloan, Reilly, and Schenzler (1994); spouse abuse by Markowitz (2000); alcohol-related motor vehicle fatalities by Young and Likens (2000); sales tax incidence by Besley and Rosen (1999); and suicides by Markowitz, Chatterji, and Dave (2002), among others.

${ }^{6}$ Young and Likens (2000) compare the logistic specification with a linear probability model and find that there are only small differences in the results.
} 
The price of alcohol, $P$, is the Stone price index, a geometric weighted average of the prices of beer, wine, and spirits, with weights equal to each beverage's share, $\theta_{j}$, in national expenditure on alcohol: ${ }^{7}$

$$
\ln P \equiv \sum_{j} \theta_{j} \ln p_{j}
$$

The coefficient, $\alpha$, on the price variable in Equation 1 is approximately the elasticity of fatalities with respect to the price of alcohol. ${ }^{8}$ For example, a coefficient of -0.1 implies that a $10 \%$ increase in alcohol prices is associated with a $1 \%$ decline in fatalities. Similarly, when the natural logarithm of per capita alcohol consumption is entered instead of price, the coefficient is approximately the elasticity of fatalities with respect to consumption.

If beverage prices are measured with error, then the price index will be correlated with the disturbance term and the OLS estimator of the price coefficient is biased and inconsistent (Greene 2003, section 5.6). If there is only a single variable subject to classical measurement error, then the OLS estimator is biased toward zero (attenuated). Similarly, if price is endogenous, it is correlated with the disturbance term, and OLS estimates a weighted average of the demand (negative) and supply (positive) coefficients. Thus, endogeneity of prices will also bias the OLS estimator away from negative values. Similar reasoning applies when alcohol consumption replaces price as a right-hand side variable. ${ }^{9}$

The biases due to measurement error and endogeneity can be eliminated by standard two-stage estimation methods if a set of proper instrumental variables can be found. Young and BielinskaKwapisz (2002) show that state and federal excise taxes and markups explain about $30 \%$ of the variation in alcohol prices in pooled cross-section time-series data similar to that employed in this study. ${ }^{10}$

Although alcohol taxes are unlikely to be correlated with errors of measurement, they may reflect unmeasured attitudes toward alcohol. In particular, taxes may be higher in states in which there is stronger anti-alcohol sentiment, or taxes may change over time in response to changes in attitudes toward alcohol. If this is the case, taxes are not proper instrumental variables. In addition, taxes may be correlated with other policies intended to reduce alcohol use, drunk driving, and/or fatalities, and data limitations may make it impossible to explicitly include these policies as control variables. In this case, taxes will be correlated with the disturbance term, and thus taxes will not be appropriately exogenous for use as instruments. ${ }^{11}$

We conclude that state and federal excise taxes and markups are likely to be good instrumental variables to deal with the measurement error problem, but may not be fully satisfactory to deal with

7 The ACCRA data are reported quarterly for a varying number of cities in each state. We aggregate to the state level by computing simple averages of the city-quarter data. Details are described in Young and Bielinska-Kwapisz (2002, 2003).

8 The elasticity is exactly equal to $(1-r) \alpha$, which is very close to $\alpha$, because $1-r \cong 0.999$.

9 Consumption may be correlated with the disturbance term because of measurement error or because some unmeasured factors are common to both drinking and fatalities. For example, some youth engage in a number of risky behaviors that include drinking, reckless driving, and/or unprotected sex (Dee and Evans 2001; Gruber 2001; Grossman, Kaestner, and Markowitz 2002). Alcohol consumption is then correlated with fatalities both because it is in fact a causal factor, and as a reflection of underlying attitudes toward risk. The latter correlation is spurious, in that a reduction in alcohol consumption-for example, as a result of higher prices-does not change attitudes toward risk. These biases in OLS estimates of the effects of consumption on fatalities are likely to operate in opposite directions: Measurement error biases the estimator toward zero, whereas spurious correlation makes the estimator too positive.

${ }^{10}$ Beer taxes by themselves explain only about $5 \%$ of alcohol price variation, and therefore are less adequate as instruments than employing the broader set of tax variables on spirits and wine, and including state markups and percentage taxes.

${ }^{11}$ See Manning, Blumberg, and Moulton (1995), footnote 4. Kubik and Moran (2003) provide evidence that changes in beer taxes are endogenous. Brown, Jewell, and Richer (1996) find that county-level prohibitions on alcohol sales are endogenous. Eisenberg (2003) concludes that existing estimates of the effects of 0.08 laws and graduated licensing programs are overstated because of endogeneity. 
problems of endogeneity/spurious correlation. The latter problem is mitigated to the extent that the regressions include socioeconomic variables, state dummies, and/or time trends that control for sentiment toward alcohol and its evolution over the sample period.

\section{Data}

The data include the contiguous states $(i=1, \ldots, 48)$ and the years $1982-2000(t=1, \ldots, 19)$, but price data are missing for various years in some states, so the total number of observations is 869 . Separate regressions are estimated for fatalities in the total population and the population aged 16-20, which we term "teen" fatalities. ${ }^{12}$ Teen fatality rates are about twice those of the total population. Both fatality rates display a significant downward trend since the early 1980s, declining by about one quarter in each case.

Separate fatality rates are also computed based on the accident day and time. Thus, weekend night fatalities, which are most likely to involve alcohol, occur between 6 p.m. Friday and 6 a.m. Saturday, and between 6 p.m. Saturday and 6 a.m. Sunday. ${ }^{13}$ Fatalities occurring between 6 a.m. and 6 p.m. Monday-Friday, plus those occurring 6 p.m. Sunday to 6 a.m. Monday, are much less likely to involve alcohol. We term these fatalities "other times." ${ }^{14}$ As Table 1a indicates, weekend night fatalities account for one fourth to one third of fatalities, even though these times account for only one seventh of the week. For the results to "make sense," these weekend night fatalities should be more closely related to alcohol prices or consumption than are fatalities at other times.

Per capita alcohol consumption declined steadily from the early 1980s to mid 1990s before leveling off at about 2.2 gallons of pure ethanol per capita (Nelson 1997; Nephew et al. 2002). The real price of alcohol generally declined except for an upward blip in 1991 when federal excise taxes increased. ${ }^{15}$

Extensive educational efforts and legal changes in the last two decades also may have affected drinking and fatalities. Seat belt laws were eventually adopted by every state, and numerous studies have concluded that fatalities declined as a result. The effects of many other laws are harder to measure, in part because states often changed several laws simultaneously, stepped up hard-tomeasure enforcement, and developed educational programs. We form an index of the legal environment by summing a series of dummy variables indicating whether or not a state has (i) an open container law, (ii) a preliminary breath test law, (iii) a dram shop law, (iv) an illegal per se blood alcohol content (BAC) level of at least 0.1 , (v) mandatory licensing action upon first conviction for driving under the influence (DUI), (vi) and an administrative per se law. ${ }^{16}$ Two more recent legal innovations are included as separate variables in order to provide evidence on their effectiveness: an illegal per se BAC level of 0.08 or less and a server training law. ${ }^{17}$ In addition, teen fatality

\footnotetext{
12 Fatality data were provided by NHTSA from the FARS database (http://www.nhtsa.dot.gov/).

13 An alternative approach is to use NHTSA's measures of alcohol-related fatalities. However, these data are imputations based on samples of drivers who were actually tested for alcohol, and these samples varied greatly over time and across states (http:// www.niaaa.nih.gov/databases/crash06.txt). Selection bias may be significant: Drivers were more likely to be tested if beer cans were found in the back seat. The current method has been used by Dee (1999) and other researchers.

${ }^{14}$ There were three instances of zero fatalities in the original data for teens during other times: North Dakota in 2000 and Rhode Island in 1993 and 1994. Since the logistic transformation can not be computed with a zero fatality rate, we assumed that one fatality occurred in each instance.

15 The price of alcohol is adjusted for national inflation using the CPI and expressed relative to the overall ACCRA cost of living in each state. It therefore represents the cost of alcohol relative to other goods, expressed in dollars of 2000 purchasing power. National averages of ACCRA prices closely follow the CPI price index for alcohol "at home." The price of alcohol "away from home" has increased faster. See Young and Bielinska-Kwapisz (2002).

${ }^{16}$ Data from NHTSA, Digest of Highway Safety Legislation, various years.

${ }^{17}$ Data on the 0.08 law is from NHTSA's Digest of Highway Safety Legislation. Server training data provided by Alexander C. Wagenaar, Alcohol Epidemiology Program, University of Minnesota, School of Public Health.
} 
Table 1a. Descriptive Statistics

\begin{tabular}{|c|c|c|c|c|c|}
\hline Variable & Definition & Mean & Standard Deviation & Minimum & Maximum \\
\hline \multicolumn{6}{|c|}{ Fatality rates (per 1000 population) } \\
\hline TOTAL & All ages, all times & 0.172 & 0.051 & 0.066 & 0.423 \\
\hline TOTALWN & All ages, weekend nights & 0.042 & 0.015 & 0.011 & 0.138 \\
\hline TOTALOT & All ages, other times & 0.087 & 0.027 & 0.029 & 0.240 \\
\hline TEEN & Ages $16-20$, all times & 0.346 & 0.106 & 0.132 & 0.937 \\
\hline TEENWN & Ages $16-20$, weekend nights & 0.115 & 0.045 & 0.022 & 0.342 \\
\hline TEENOT & Ages $16-20$, other times & 0.138 & 0.048 & 0.020 & 0.511 \\
\hline \multicolumn{6}{|c|}{ RHS endogenous variables } \\
\hline$A C O N$ & Ethanol consumption (gal/capita) & 2.37 & 0.430 & 1.24 & 5.26 \\
\hline APRICE & Ethanol price (\$/gal) & 269.3 & 25.0 & 212.6 & 337.8 \\
\hline \multicolumn{6}{|c|}{ RHS exogenous variables } \\
\hline SBELT & Seat belt law $=1$ & 0.760 & 0.427 & 0.0 & 1.0 \\
\hline LEGALENV & Legal environment index & 3.27 & 1.07 & 1.0 & 6.0 \\
\hline ILLPER08 & Illegal per se 0.08 & 0.180 & 0.384 & 0.0 & 1.0 \\
\hline SERVTRAN & Server training law & 0.237 & 0.422 & 0.0 & 1.0 \\
\hline INCOME & Income per capita $(\$ 000 \mathrm{~s})$ & 25.3 & 3.12 & 15.3 & 36.7 \\
\hline VMTLIC & Vehicle miles traveled (000s/driver) & 12.9 & 2.09 & 7.75 & 22.4 \\
\hline$D R Y$ & Population living in dry areas (\%) & 4.28 & 8.49 & 0.0 & 46.4 \\
\hline POP1829 & Population ages $18-29(\%)$ & 18.72 & 2.30 & 13.82 & 24.0 \\
\hline DRINKAGE & Legal drinking age & 20.7 & 0.749 & 18.0 & 21.0 \\
\hline KEGREG & Keg registration & 0.110 & 0.312 & 0.0 & 1.0 \\
\hline YOUTHBAC & Lower BAC for youth $=1$ & 0.420 & 0.485 & 0.0 & 1.0 \\
\hline CATHOLIC & Catholic (\%) & 21.1 & 12.3 & 1.74 & 63.5 \\
\hline MORMON & Mormon (\%) & 1.51 & 6.51 & 0.1 & 76.2 \\
\hline SBAPTIST & Southern Baptist (\%) & 7.96 & 10.1 & 0.0 & 37.4 \\
\hline POP65 & Population ages $65+(\%)$ & 12.4 & 2.04 & 7.6 & 18.6 \\
\hline TOURISM & Share of GSP from hotels/restaurants (\%) & 0.76 & 1.03 & 0.27 & 15.1 \\
\hline
\end{tabular}

regressions include several laws directed specifically at this age group: the legal drinking age, keg registration, and the existence of a separate (lower) BAC level for teens. ${ }^{18}$

Controls are also included for the percentages of the population that are Catholic, Mormon, and Southern Baptist; the percentage of the population over age 65; and a tourism variable measuring the percentage of gross state product from the hotel and restaurant industry. ${ }^{19}$ In addition to an indirect effect on fatalities via alcohol consumption, these factors may also have a direct effect on fatalities, and the relationships may sometimes be conflicting. For example, the population over 65 tends to drink less, but are more likely to be involved in fatal accidents.

Table $1 \mathrm{~b}$ displays descriptive statistics on the tax measures used as instruments for prices and consumption (DISCUS 2000). All states employ per unit excise taxes on beer, wine, and spirits. In addition, control states levy taxes and/or markups based on the wholesale prices of spirits and wine. Instrumental variable estimation is performed in LIMDEP $8.0{ }^{20}$ First stage squared correlations

\footnotetext{
${ }^{18} \mathrm{Keg}$ registration and youth BAC from Wagenaar, Ibid.

${ }^{19}$ Religion variables are interpolations/extrapolations based on Quinn et al. (1980) and Bradley et al. (1990). Age data from U.S. Bureau of the Census. Tourism data from the U.S. Bureau of Economic Analysis (http://www.bea.doc.gov/bea/regional/gsp/).

${ }^{20}$ See Greene (2002), section E8.5.12 for details.
} 
Table 1b. Instrumental Variables

\begin{tabular}{llcccc}
\hline Variable & \multicolumn{1}{c}{ Definition } & Mean & Standard Deviation & Minimum & Maximum \\
\hline BTAX & Beer excise tax (\$/gal) & 18.86 & 6.64 & 8.57 & 52.95 \\
WTAX & Wine excise tax (\$/gal) & 11.69 & 6.91 & 1.55 & 31.78 \\
STAX & Spirits excise tax (\$/gal) & 40.58 & 7.46 & 22.6 & 66.4 \\
STAXPERC & Spirits excise tax (\%) & 3.72 & 9.52 & 0.0 & 56.0 \\
SMARKUP & Spirits markup (\%) & 12.7 & 22.4 & 0.0 & 113.0 \\
WTAXPER & Wine excise tax (\%) & 1.06 & 4.10 & 0.0 & 35.0 \\
WMARKUP & Wine markup (\%) & 2.61 & 10.0 & 0.0 & 84.2 \\
\hline
\end{tabular}

Means and standard deviations are weighted by state population; $N=869$.

between the fitted and actual values for price and consumption are, respectively, 0.90 and 0.98 . The lower $R^{2}$ for price is consistent with a larger amount of measurement error in that variable. ${ }^{21}$

\section{Results}

Hausman tests for measurement error and/or endogeneity of prices are displayed in Table 2a (Davidson and MacKinnon 1989, 1993). The null hypothesis of exogeneity is rejected at the $1 \%$ level for five of the six fatality rates. As the last two columns indicate, correcting for measurement error/ endogeneity has a profound impact on the estimated price effects. OLS estimates are positive for five of the six fatality rates, and three of the estimates are statistically significant. Taken at face value, these estimates imply that increases in alcohol prices are positively associated with traffic fatalities. However, the IV estimates imply quite the opposite: All six of the estimates are negative, and five of the six are significant at the $5 \%$ level.

The estimated magnitudes suggest substantial effects of prices on fatalities. A $10 \%$ increase in alcohol prices is predicted to reduce total fatalities by $5.8 \%$. The estimated effect is somewhat larger for weekend night fatalities (6.9\%), and smaller for other times (3.9\%). The estimated impact on all youth fatalities (9\%) is larger than for the total population. Less plausibly, the estimated impact on weekend night fatalities among youth $(3.5 \%)$ is smaller than the impact on youth at other times $(9.3 \%)$, although the difference is not significant at the 0.05 level.

The results using alcohol consumption in place of price are broadly similar. Exogeneity is rejected at the $10 \%$ significance level or less for five of the six fatality rates, and instrumental variable estimates indicate larger effects than do OLS estimates. For example, using OLS, a $10 \%$ increase in per capita alcohol consumption is associated with a $9.9 \%$ increase in fatalities, whereas the IV estimate is $11.3 \%$. The other estimated effects range from $10.2 \%$ to $14.1 \%$. Somewhat implausibly, the estimated effects are smaller on weekend night fatalities than on fatalities at other times, particularly for youth, although the difference is again not statistically significant.

The regressions also provide evidence on a number of other determinants of fatalities. Among the total population (Table 3), income, vehicle miles traveled, and the population 18-29 years are positively and significantly related to fatalities in most specifications. Seat belt laws reduce fatalities $4-6 \%$. The evidence is less strong for the legal environment index, which is negative for five of six fatality rates, but not always statistically significant. ${ }^{22}$ The percentage of the population living in dry

\footnotetext{
${ }^{21}$ Tax coefficients from the first-stage regressions are displayed in Table A1.

${ }^{22}$ Entering the components of the index as separate variables results in about half negative and half positive coefficients, many of which are not significant. It appears that the data are not sufficiently strong to distinguish among the effects of the large number of legal initiatives that states have implemented.
} 
Table 2a. Tests for Endogeneity and/or Measurement Error in Prices

\begin{tabular}{lccc}
\hline & \multirow{2}{*}{$\begin{array}{c}\text { Pvalue } \\
\text { Fatality Rate }\end{array}$} & \multicolumn{2}{c}{ Price Coefficient $\mid t$-ratio $\mid$} \\
\cline { 3 - 4 } All ages & 28.4 & 0.16 & IV \\
All times & $(0.00)$ & 2.2 & -0.58 \\
All ages & 17.3 & 0.11 & 3.4 \\
Weekend nights & $(0.00)$ & 1.1 & -0.69 \\
All ages & 12.6 & 0.29 & 3.0 \\
Other times & $(0.00)$ & 3.5 & -0.39 \\
Ages 16-20 & 15.3 & 0.08 & 2.1 \\
All times & $(0.00)$ & 0.7 & -0.90 \\
Ages 16-20 & 0.4 & -0.10 & 3.1 \\
Weekend nights & $(0.52)$ & 0.5 & -0.35 \\
Ages 16-20 & 12.7 & 0.44 & 0.8 \\
Other times & $(0.00)$ & 2.6 & -0.93 \\
& & & 2.2 \\
\hline
\end{tabular}

counties has no effect on fatalities, conditional on the price of alcohol. However, percentage living in dry counties is positively related to fatalities, conditional on alcohol consumption. This is consistent with the hypothesis that dry counties have a mixed relationship with fatalities: (i) more people living in dry counties is associated with a lower demand for alcohol, and on that account fewer fatalities; (ii) at the same time, people who do drink may be more likely to drive to obtain alcohol, and on that account result in more fatalities (Baughman et al. 2001).

There is little evidence that 0.08 laws or server training are effective in reducing fatalities. Membership in the Catholic church is negatively related to fatalities, significantly so in two of three equations. The percentage Mormon is not significant, whereas fatalities are positively and significantly related to Southern Baptist membership. The latter relationship is unexpected, because many Southern Baptists preach abstinence. Fatalities are positively related to the population aged 65 and above, apparently because fatality rates are higher for this group. Tourism is not significantly related to fatalities.

Results for teenagers (age 16-20) are broadly similar (Table 4). Increasing the drinking age by one year is estimated to reduce teen fatalities by $1-3 \%$, with the largest estimated impact on weekend night fatalities. There is some evidence that keg registration is associated with lower teen fatalities, but not on weekend nights. A youth BAC law is not significantly related to fatalities.

Table 5 assesses the robustness of the results by varying the estimation technique and/or specification. These results use price as the right-hand side variable and total fatalities (all times) as the dependent variable. One concern is that logit specifications are sometimes sensitive to weighting. ${ }^{23}$ Columns 1 and 4 of Table 5 display results for all ages and for teens with no weights; that is, unweighted two-stage least squares estimates. Standard errors are computed using White's correction for groupwise heteroskedasticity, assuming that variances differ among states (Greene 2002). In comparison with the weighted estimates in Tables 3 and 4, the unweighted price coefficient is slightly larger for all ages and slightly smaller for teens. Both remain statistically significant. Thus, there is little evidence that weighting has an important influence on the results.

With state and year dummies included, our estimates are equivalent to "difference-in-difference" estimates, which are sometimes misleading because of serial correlation (Bertrand, Duflo, and

\footnotetext{
${ }^{23}$ Most of the variation in weights is attributable to differences in population, which ranges from $34,000,000$ in California in 2000 to 450,000 in Wyoming in 1990.
} 
Table 2b. Tests for Endogeneity and/or Measurement Error in Consumption

\begin{tabular}{lccc}
\hline & \multirow{2}{*}{$\begin{array}{c}\text { Consumption Coefficient } \\
\text { Fatality Rate }\end{array}$} & -ratio $\mid$ \\
\cline { 2 - 4 } (Significance Level) & 10.7 & 0.99 & IV \\
\hline All ages & $(0.00)$ & 16.8 & 1.13 \\
All times & 3.1 & 0.99 & 14.4 \\
All ages & $(0.08)$ & 12.4 & 1.08 \\
Weekend nights & 12.1 & 0.91 & 9.5 \\
All ages & $(0.00)$ & 12.9 & 1.11 \\
Other times & 12.6 & 0.97 & 11.7 \\
Ages 16-20 & $(0.00)$ & 9.2 & 1.29 \\
All times & 1.4 & 0.86 & 8.9 \\
Ages 16-20 & $(0.23)$ & 5.0 & 1.02 \\
Weekend nights & 13.8 & 0.85 & 4.3 \\
Ages 16-20 & $(0.00)$ & 5.3 & 1.41 \\
Other times & & & 6.3 \\
\hline
\end{tabular}

Mullainathan 2004). Columns 2 and 5 of Table 5 provide estimates corrected for first-order serial correlation (AR1). ${ }^{24}$ There is little effect on the magnitudes of the estimated coefficients. $T$-ratios are mostly smaller, but the pattern of significant and insignificant coefficients is largely unaffected.

There are substantially different results when some of the control variables are omitted. We experimented with dropping variables whose estimated coefficients were consistently of "wrong" sign and/or insignificant (population in dry counties, $\mathrm{BAC}=0.08$, server training, and tourism). We also dropped the three religion variables, which are time trends based on two observations from each state, and were also often insignificant or of unexpected sign. As columns 3 and 6 of Table 5 indicate, omitting these variables markedly reduces the magnitude of the estimated price response. The elasticity of fatalities with respect to the price of alcohol falls to 0.3 for adults and 0.2 for teens, and the teen estimate is not significantly different from zero. Most of the rest of the coefficients display smaller changes in magnitude and statistical significance. An exception is keg registration, which becomes highly significant and is estimated to reduce fatalities by $13 \%$. Overall, these results suggest that point estimates should be treated with caution, as they appear to depend on the exact specification of the regression.

\section{Discussion}

There is strong evidence of measurement error and/or endogeneity in the ACCRA price data for alcohol, which biases conventional (OLS) estimators toward a finding of little or no effect of prices on traffic fatalities. Using state and federal tax rates as instrumental variables, there is strong evidence in most specifications that fatalities are in fact negatively and significantly related to the price of alcohol, ceteris paribus. Our point estimates indicate that an increase in the beer tax of 50 cents per six pack of beer would reduce traffic fatalities by about 4.5\%; this amounted to 1900 lives in the year 2000 . Qualitatively similar results hold for the relationship between alcohol consumption and fatalities: Estimates based on instrumental variable techniques are larger than those from OLS.

Are the partial reduced-form estimates of the price-fatality relationship consistent with structural estimates of the effects of price on consumption and consumption on fatalities? By definition, the elasticity of fatalities with respect to the price of alcohol, $E_{f p}$ say, is equal to the product of the priceconsumption elasticity, $E_{c p}$, and the consumption-fatality elasticity, $E_{f c}$. Our basic point estimates thus

\footnotetext{
${ }^{24}$ Estimated rho is 0.46 for all ages and 0.12 for teens.
} 
Table 3. Fatality Regressions for Total Population (All Ages)

\begin{tabular}{|c|c|c|c|c|c|c|}
\hline \multirow[b]{2}{*}{ Right-hand Side Variable } & \multicolumn{3}{|c|}{ Alcohol Price } & \multicolumn{3}{|c|}{ Alcohol Consumption } \\
\hline & $\begin{array}{c}\text { All } \\
\text { Times }\end{array}$ & $\begin{array}{c}\text { Weekend } \\
\text { Nights }\end{array}$ & $\begin{array}{l}\text { Other } \\
\text { Times }\end{array}$ & $\begin{array}{c}\text { All } \\
\text { Times }\end{array}$ & $\begin{array}{c}\text { Weekend } \\
\text { Nights }\end{array}$ & $\begin{array}{l}\text { Other } \\
\text { Times }\end{array}$ \\
\hline ln (alcohol price) & $\begin{array}{c}-0.58 \\
3.4\end{array}$ & $\begin{array}{c}-0.69 \\
3.0\end{array}$ & $\begin{array}{c}-0.39 \\
2.1\end{array}$ & & & \\
\hline Ln (alcohol consumption) & & & & $\begin{array}{c}1.13 \\
14.4\end{array}$ & $\begin{array}{l}1.08 \\
9.5\end{array}$ & $\begin{array}{c}1.11 \\
11.7\end{array}$ \\
\hline Income & $\begin{array}{l}0.045 \\
11.7\end{array}$ & $\begin{array}{l}0.040 \\
7.7\end{array}$ & $\begin{array}{c}0.045 \\
10.6\end{array}$ & $\begin{array}{l}0.017 \\
5.6\end{array}$ & $\begin{array}{l}0.010 \\
2.2\end{array}$ & $\begin{array}{l}0.022 \\
5.9\end{array}$ \\
\hline VMTLIC & $\begin{array}{l}0.022 \\
5.4\end{array}$ & $\begin{array}{l}0.014 \\
2.5\end{array}$ & $\begin{array}{l}0.022 \\
5.0\end{array}$ & $\begin{array}{l}0.009 \\
2.6\end{array}$ & $\begin{array}{l}0.003 \\
0.5\end{array}$ & $\begin{array}{l}0.010 \\
2.3\end{array}$ \\
\hline Population $18-29(\%)$ & $\begin{array}{l}0.051 \\
7.2\end{array}$ & $\begin{array}{l}0.037 \\
3.7\end{array}$ & $\begin{array}{l}0.055 \\
7.0\end{array}$ & $\begin{array}{l}0.029 \\
5.3\end{array}$ & $\begin{array}{l}0.023 \\
2.8\end{array}$ & $\begin{array}{l}0.030 \\
4.8\end{array}$ \\
\hline Seat belt law & $\begin{array}{c}-0.038 \\
3.1\end{array}$ & $\begin{array}{c}-0.045 \\
2.8\end{array}$ & $\begin{array}{c}-0.041 \\
3.1\end{array}$ & $\begin{array}{c}-0.043 \\
4.3\end{array}$ & $\begin{array}{c}-0.055 \\
3.8\end{array}$ & $\begin{array}{c}-0.046 \\
3.8\end{array}$ \\
\hline Legal environment & $\begin{array}{c}-0.004 \\
0.8\end{array}$ & $\begin{array}{c}-0.011 \\
1.8\end{array}$ & $\begin{array}{l}0.001 \\
0.2\end{array}$ & $\begin{array}{c}-0.008 \\
2.1\end{array}$ & $\begin{array}{c}-0.017 \\
3.1\end{array}$ & $\begin{array}{c}-0.002 \\
0.4\end{array}$ \\
\hline Population in dry counties (\%) & $\begin{array}{l}0.001 \\
0.5\end{array}$ & $\begin{array}{l}0.005 \\
1.5\end{array}$ & $\begin{array}{c}-0.002 \\
0.6\end{array}$ & $\begin{array}{l}0.009 \\
3.9\end{array}$ & $\begin{array}{l}0.013 \\
4.0\end{array}$ & $\begin{array}{l}0.005 \\
1.8\end{array}$ \\
\hline $\mathrm{BAC}=0.08$ & $\begin{array}{l}0.027 \\
2.2\end{array}$ & $\begin{array}{l}0.034 \\
1.9\end{array}$ & $\begin{array}{l}0.010 \\
0.7\end{array}$ & $\begin{array}{l}0.008 \\
0.9\end{array}$ & $\begin{array}{l}0.008 \\
0.6\end{array}$ & $\begin{array}{c}-0.003 \\
0.3\end{array}$ \\
\hline Server training & $\begin{array}{c}-0.004 \\
0.4\end{array}$ & $\begin{array}{l}0.011 \\
0.7\end{array}$ & $\begin{array}{c}-0.009 \\
0.7\end{array}$ & $\begin{array}{c}-0.012 \\
1.4\end{array}$ & $\begin{array}{l}0.006 \\
0.5\end{array}$ & $\begin{array}{c}-0.018 \\
1.6\end{array}$ \\
\hline Catholic (\%) & $\begin{array}{c}-0.009 \\
4.1\end{array}$ & $\begin{array}{c}-0.003 \\
0.9\end{array}$ & $\begin{array}{c}-0.013 \\
5.1\end{array}$ & & & \\
\hline Mormon (\%) & $\begin{array}{c}-0.010 \\
0.8\end{array}$ & $\begin{array}{l}0.010 \\
0.5\end{array}$ & $\begin{array}{c}-0.021 \\
1.5\end{array}$ & & & \\
\hline Southern Baptist (\%) & $\begin{array}{l}0.045 \\
7.9\end{array}$ & $\begin{array}{l}0.055 \\
7.0\end{array}$ & $\begin{array}{l}0.038 \\
6.0\end{array}$ & & & \\
\hline Population $65+(\%)$ & $\begin{array}{l}0.024 \\
2.1\end{array}$ & $\begin{array}{l}0.026 \\
1.7\end{array}$ & $\begin{array}{l}0.024 \\
1.9\end{array}$ & & & \\
\hline Tourism $(\%)$ & $\begin{array}{c}-0.021 \\
1.0\end{array}$ & $\begin{array}{c}-0.028 \\
1.0\end{array}$ & $\begin{array}{c}-0.015 \\
0.7\end{array}$ & & & \\
\hline Adjusted $R^{2}$ & 0.94 & 0.91 & 0.92 & 0.94 & 0.93 & 0.93 \\
\hline
\end{tabular}

State and year dummies are included in every equation. Estimation is by 2 SLS using combined state plus federal excise taxes on beer, spirits, and wine, and for control states, the percentage excise taxes and/or markups on spirits and wine, as applicable. Price or consumption is treated as endogenous. $N=869$. Dependent variable: logit of fatality rate (absolute values of $t$-statistics are below parameter estimates).

imply the price-consumption elasticity is $E_{c p}=E_{f c} / E_{f p}=-0.58 / 1.13=-0.51$. This value is within the range of price elasticities for aggregate alcohol consumption estimated in previous work (Leung and Phelps 1993; Young and Bielinska-Kwapisz 2003).

What do these estimates imply about the impact of alcohol taxes on traffic fatalities? The answer depends on the degree to which alcohol taxes are shifted forward to retail prices and on how important taxes are as a share of retail prices. Young and Bielinska-Kwapisz (2002) found that spirits, beer, and wine taxes are overshifted: Retail prices rise more than one-for-one with an increase in taxes. However, excise taxes are only 11-18\% of retail prices. Thus, the 1991 change in federal excise taxes, which doubled the beer tax from 16 cents per six pack of beer to 32 cents and increased the wine tax by $500 \%$, increased retail prices by only about $6 \%$. Based on a price-fatality elasticity of 0.58 , the predicted decline in total fatalities is about $3.5 \%$. 
Table 4. Fatality Regressions for Teens (Ages 16-20)

\begin{tabular}{|c|c|c|c|c|c|c|}
\hline \multirow[b]{2}{*}{ Right-hand Side Variable } & \multicolumn{3}{|c|}{ Alcohol Price } & \multicolumn{3}{|c|}{ Alcohol Consumption } \\
\hline & All Times & Weekend Nights & Other Times & All Times & Weekend Nights & Other Times \\
\hline \multirow[t]{2}{*}{$\ln$ (alcohol price) } & -0.89 & -0.35 & -0.93 & & & \\
\hline & 3.1 & 0.8 & 2.2 & & & \\
\hline \multirow[t]{2}{*}{ Ln (alcohol consumption) } & & & & 1.29 & 1.02 & 1.41 \\
\hline & & & & 8.9 & 4.3 & 6.3 \\
\hline \multirow[t]{2}{*}{ Income } & 0.055 & 0.041 & 0.065 & 0.023 & 0.016 & 0.033 \\
\hline & 9.4 & 4.5 & 7.5 & 4.3 & 1.8 & 4.0 \\
\hline \multirow[t]{2}{*}{ VMTLIC } & 0.031 & 0.015 & 0.041 & 0.015 & 0.008 & 0.022 \\
\hline & 5.0 & 1.6 & 4.5 & 2.5 & 0.8 & 2.3 \\
\hline \multirow[t]{2}{*}{ Drinking age } & -0.019 & -0.022 & -0.011 & -0.023 & -0.028 & -0.014 \\
\hline & 2.3 & 1.7 & 0.8 & 3.0 & 2.3 & 1.2 \\
\hline \multirow[t]{2}{*}{ Seat belt law } & -0.042 & -0.057 & -0.046 & -0.055 & -0.071 & -0.057 \\
\hline & 2.3 & 2.1 & 1.7 & 3.2 & 2.6 & 2.1 \\
\hline \multirow[t]{2}{*}{ Legal environment } & -0.002 & 0.010 & -0.012 & -0.008 & 0.003 & -0.016 \\
\hline & 0.3 & 1.0 & 1.2 & 1.2 & 0.3 & 1.6 \\
\hline \multirow[t]{2}{*}{ Population in dry counties $(\%)$} & -0.005 & -0.000 & -0.013 & 0.004 & 0.005 & -0.003 \\
\hline & 1.2 & 0.0 & 1.8 & 0.9 & 0.8 & 0.4 \\
\hline \multirow[t]{2}{*}{$\mathrm{BAC}=0.08$} & 0.078 & 0.052 & 0.041 & -0.040 & 0.027 & 0.005 \\
\hline & 4.0 & 1.7 & 1.4 & 2.4 & 1.0 & 0.2 \\
\hline \multirow[t]{2}{*}{ Server training } & -0.006 & 0.021 & -0.015 & -0.006 & 0.023 & -0.019 \\
\hline & 0.4 & 0.8 & 0.6 & 0.4 & 0.9 & 0.8 \\
\hline \multirow[t]{2}{*}{ Catholic (\%) } & -0.008 & -0.003 & -0.014 & & & \\
\hline & 2.3 & 0.5 & 2.7 & & & \\
\hline \multirow[t]{2}{*}{ Mormon (\%) } & -0.023 & -0.037 & -0.046 & & & \\
\hline & 1.3 & 1.1 & 1.9 & & & \\
\hline \multirow[t]{2}{*}{ Southern Baptist (\%) } & 0.059 & 0.058 & 0.056 & & & \\
\hline & 6.9 & 4.4 & 4.5 & & & \\
\hline \multirow[t]{2}{*}{ Keg registration } & -0.127 & -0.034 & -0.182 & -0.039 & 0.019 & -0.091 \\
\hline & 4.9 & 0.8 & 4.8 & 1.6 & 0.5 & 2.5 \\
\hline \multirow[t]{2}{*}{ Youth BAC } & -0.009 & -0.019 & 0.013 & 0.006 & -0.005 & 0.026 \\
\hline & 0.5 & 0.7 & 0.5 & 0.4 & 0.2 & 1.1 \\
\hline Adjusted $R^{2}$ & 0.85 & 0.79 & 0.76 & 0.87 & 0.79 & 0.77 \\
\hline
\end{tabular}

State and year dummies are included in every equation. Estimation is by 2SLS using combined state plus federal excise taxes on beer, spirits, and wine, and for control states, the percentage excise taxes and/or markups on spirits and wine, as applicable. Price or consumption is treated as endogenous. $N=869$. Dependent variable: logit of fatality rate (absolute values of $t$-statistics are below parameter estimates).

These results can also be expressed as a tax-fatality elasticity. Ignoring the increase in the wine tax for simplicity, the implied elasticity of fatalities with respect to the beer tax is 0.06 . This figure is about one quarter lower than Evans, Neville, and Graham's (1991) estimate of 0.08, and about one half of Ruhm's (1996, table 2) estimate of 0.11. Chaloupka, Saffer, and Grossman (1993, p. 181) estimated that doubling the federal beer tax would have reduced fatalities by $3.9 \%$, similar to the finding in this paper.

The estimated tax elasticity for teen fatalities is about half again as large (0.09), because the teen price elasticity of fatalities is estimated to be that much larger (Tables 2 and 4). This value is substantially smaller than some previous estimates. For example, Ruhm's (1996, table 4) tax elasticity for 18- to 20-year-olds is twice as high (0.17-0.21), and Chaloupka, Saffer, and Grossman (1993, p. 181) report that doubling the federal beer tax would reduce fatalities among 18 - to 20 -year-olds by $11.8 \%$, implying an even larger tax elasticity of 0.21 . 
Table 5. Robustness Checks

\begin{tabular}{|c|c|c|c|c|c|c|}
\hline \multirow[b]{2}{*}{ Right-hand Side Variable } & \multicolumn{3}{|c|}{ All Ages } & \multicolumn{3}{|c|}{ Teens } \\
\hline & Unweighted & $\begin{array}{c}\text { AR1 } \\
\text { Corrected }\end{array}$ & $\begin{array}{c}\text { Omit } \\
\text { Some } X \mathrm{~s}\end{array}$ & Unweighted & $\begin{array}{c}\text { AR1 } \\
\text { Corrected }\end{array}$ & $\begin{array}{c}\text { Omit Some } \\
X \mathrm{~s}\end{array}$ \\
\hline \multirow[t]{2}{*}{ ln (alcohol price) } & -0.70 & -0.77 & -0.31 & -0.84 & -0.74 & -0.19 \\
\hline & 3.8 & 2.8 & 2.2 & 2.5 & 1.8 & 0.9 \\
\hline \multirow[t]{2}{*}{ Income } & 0.036 & 0.026 & 0.041 & 0.048 & 0.041 & 0.044 \\
\hline & 8.2 & 4.2 & 12.7 & 6.5 & 4.6 & 8.7 \\
\hline \multirow{2}{*}{ VMTLIC } & 0.020 & 0.007 & 0.030 & 0.028 & 0.021 & 0.038 \\
\hline & 5.2 & 1.4 & 7.9 & 4.0 & 2.7 & 6.8 \\
\hline \multirow{2}{*}{ Population 18-29 (\%) } & 0.054 & 0.053 & 0.062 & & & \\
\hline & 8.8 & 5.2 & 9.8 & & & \\
\hline \multirow[t]{2}{*}{ Seat belt law } & -0.030 & -0.031 & -0.023 & -0.017 & -0.029 & -0.026 \\
\hline & 2.5 & 2.3 & 2.0 & 0.8 & 1.3 & 1.5 \\
\hline \multirow{2}{*}{ Legal environment } & -0.008 & -0.008 & -0.004 & -0.013 & -0.010 & -0.008 \\
\hline & 1.8 & 1.3 & 1.0 & 1.7 & 1.0 & 1.3 \\
\hline \multirow[t]{2}{*}{ Population in dry counties (\%) } & 0.001 & 0.001 & & -0.004 & -0.005 & \\
\hline & 0.3 & 0.2 & & 0.8 & 0.7 & \\
\hline \multirow[t]{2}{*}{$\mathrm{BAC}=0.08$} & 0.013 & 0.022 & & 0.038 & 0.027 & \\
\hline & 1.0 & 1.1 & & 1.6 & 0.9 & \\
\hline \multirow{2}{*}{ Server training } & -0.023 & -0.017 & & 0.000 & 0.008 & \\
\hline & 2.0 & 0.9 & & 0.0 & 0.3 & \\
\hline \multirow[t]{2}{*}{ Catholic (\%) } & -0.005 & 0.005 & & 0.010 & 0.006 & \\
\hline & 2.0 & 0.0 & & 2.4 & 1.0 & \\
\hline \multirow[t]{2}{*}{ Mormon (\%) } & -0.008 & -0.013 & & -0.010 & -0.013 & \\
\hline & 1.0 & 0.7 & & 0.7 & 0.7 & \\
\hline \multirow[t]{2}{*}{ Southern Baptist (\%) } & 0.041 & 0.058 & & 0.056 & 0.064 & \\
\hline & 6.9 & 5.4 & & 6.4 & 5.1 & \\
\hline \multirow[t]{2}{*}{ Population $65+(\%)$} & 0.027 & 0.029 & 0.034 & & & \\
\hline & 2.4 & 1.5 & 3.2 & & & \\
\hline \multirow[t]{2}{*}{ Tourism $(\%)$} & -0.018 & 0.018 & & & & \\
\hline & 1.4 & 0.7 & & & & \\
\hline \multirow[t]{2}{*}{ Drinking age } & & & & -0.002 & -0.001 & -0.013 \\
\hline & & & & 0.2 & 0.1 & 1.6 \\
\hline \multirow{2}{*}{ Keg registration } & & & & -0.059 & -0.034 & -0.130 \\
\hline & & & & 1.9 & 0.9 & 5.5 \\
\hline \multirow[t]{2}{*}{ Youth BAC } & & & & -0.018 & -0.020 & -0.003 \\
\hline & & & & 0.9 & 0.8 & 0.2 \\
\hline Adjusted $R^{2}$ & 0.92 & 0.82 & 0.93 & 0.78 & 0.75 & 0.86 \\
\hline
\end{tabular}

Dependent variable: logit of fatality rate (absolute values of $t$-statistics below parameter estimates).

Even these more modest estimates obtained in this study should be regarded with caution, however. One reason is that they still seem too large. Only a minority of fatalities involve alcohol; currently the proportion is $30-40 \%$. Thus, a $1 \%$ increase in per capita alcohol consumption could increase fatalities by $1.13 \%$ only if alcohol-involved fatalities increase by more than twice that amount. Second, the pattern of estimated price and consumption effects across the different fatality measures is sometimes counterintuitive. Teen fatalities on weekend nights are apparently less responsive to the price of alcohol than are fatalities at other times, and total fatalities on weekend nights are apparently less responsive to alcohol consumption than fatalities at other times. ${ }^{25}$

\footnotetext{
25 Dee (1999) and Dee and Evans (2001) obtain similar results.
} 
In part, these results may reflect "small and infrequent changes in state excise taxes" (Cook and Moore 2001, p. 421). In addition, point estimates of price effects are sensitive to what other control variables are included, with much more modest effects obtained when some of the insignificant variables are excluded.

A related concern is that alcohol taxes and other policies may reflect underlying attitudes toward alcohol, or be correlated with unmeasured policy measures intended to curb fatalities, and thus be improper instrumental variables. In particular, to the extent that states simultaneously took action on a number of fronts to reduce alcohol abuse-say by increasing taxes, legislating stricter and more certain penalties for DUI, stepping up enforcement and educational efforts, and mobilizing citizen groups - then the estimated effects of taxes are likely to overstate their actual deterrent effects.

The problem of "endogenous policy" is not confined to this study. Whether a researcher takes a "structural" approach as is done here, or instead estimates a "reduced form" by regressing fatalities directly on taxes, the resulting estimators are biased and inconsistent if taxes are endogenous. Indeed, all of the most frequently cited estimates of the impact of alcohol taxes rely on the assumption that taxes are exogenous. Thus, all of these studies may be biased, and a more accurate assessment will not be possible until the determinants of policy are more fully understood and estimation procedures are modified accordingly. This study has substantially resolved the discrepancy between estimates based on tax and price data, but it remains to be seen whether the tax data themselves are appropriate as exogenous variables.

Table A1. Tax Coefficients from First-stage Regressions

\begin{tabular}{lcc}
\hline & \multicolumn{2}{c}{ Dependent Variable } \\
\cline { 2 - 3 } Right-hand Side Variable & $\begin{array}{c}\text { Log of Ethanol } \\
\text { Consumption }\end{array}$ & $\begin{array}{c}\text { Log of Ethanol } \\
\text { Price }\end{array}$ \\
\hline Real beer excise tax & -0.01 & 0.0041 \\
& 3.4 & 2.98 \\
Real wine excise tax & 0.0014 & 0.0027 \\
& 1.1 & 1.75 \\
Real spirits excise tax & -0.005 & 0.0053 \\
& -5.6 & 4.5 \\
Spirits excise tax (\%) & 0.001 & 0.0016 \\
Spirits markup (\%) & 0.6 & 1.2 \\
Wine excise tax (\%) & -0.0004 & 0.00064 \\
& 1.6 & 1.9 \\
Wine markup (\%) & -0.0007 & 0.0034 \\
Adjusted $R^{2}$ & 0.7 & 2.7 \\
\hline
\end{tabular}

Absolute values of $t$-statistics below parameter estimates. Each equation also includes all of the right-hand side exogenous variables from the structural fatality equations (see Table 3). 


\section{References}

American Chamber of Commerce Researchers Association (ACCRA). 1982-2000. ACCRA cost of living index, quarterly reports. Louisville, KY: ACCRA.

Baughman, Reagan, Michael Conlin, Stacy Dickert-Conlin, and John Pepper. 2001. Slippery when wet: The effects of local alcohol access laws on highway safety. Journal of Health Economics 20:1089-196.

Beard, T. Randolph, Paula A. Gant, and Richard P. Saba. 1997. Border-crossing sales, tax avoidance, and state tax policies: An application to alcohol. Southern Economic Journal 641:293-306.

Bertrand, Marianne, Esther Duflo, and Sendhil Mullainathan. 2004. How much should we trust difference-in-differences estimates? Quarterly Journal of Economics 119(1):249-75.

Besley, Timothy J., and Harvey S. Rosen. 1999. Sales taxes and prices: An empirical analysis. National Tax Journal June: 157-78.

Bradley, Martin B., Norman M. Green, Jr., Dale E. Jones, Mac Lynn, and Lou McNeil. 1990. Churches and church membership in the United States 1990. Atlanta: Glemnary Research Center.

Brown, Robert, R. Todd Jewell, and Jerell Richer. 1996. Endogenous alcohol prohibition and drunk driving. Southern Economic Journal 62:1043-53.

$\rightarrow$ Chaloupka, F. J., H. Saffer, and M. Grossman. 1993. Alcohol control policies and motor-vehicle fatalities. Journal of Legal Studies 22(1):161-86.

Cook, Phillip J. 1981. The effect of liquor taxes on drinking, cirrhosis, and auto fatalities. In Alcohol and public policy: Beyond the shadow of prohibition, edited by M. H. Moore and D. R. Gerstein. Washington, DC: National Academy Press, pp. 255-85.

Cook, Philip J., and Michael J. Moore. 2001. Environment and persistence in youthful drinking patterns. In Risky behavior among youths, edited by Jonathon Gruber. Chicago: University of Chicago Press, pp. 375-437.

$\rightarrow$ Davidson, Russell, and James G. MacKinnon. 1989. Testing for consistency using artificial regressions. Econometric Theory 5:363-84.

Davidson, Russell, and James G. MacKinnon. 1993. Estimation and inference in econometrics. New York: Oxford University Press.

Dee, Thomas S. 1999. State alcohol policies, teen drinking, and traffic fatalities. Journal of Public Economics 72:289-315.

Dee, Thomas S., and William N. Evans. 2001. Teens and traffic safety. In Risky behavior among youths, edited by Jonathon Gruber. Chicago: University of Chicago Press, pp. 121-65.

Distilled Spirits Council of the U.S. (DISCUS). 2000. History of beverage alcohol tax changes. Washington, DC: DISCUS.

$\rightarrow$ Eisenberg, Daniel. 2003. Evaluating the effectiveness of policies related to drunk driving. Journal of Policy Analysis and Management 22:249-74.

Evans, W. N., D. Neville, and J. Graham. 1991. General deterrence of drunk driving: Evaluation of recent American policies. Risk Analysis 11:279-89.

Greene, William H. 2002. LIMDEP version 8.0 econometric modeling guide. Volume 2. Plainview, NY: Econometric Software, Inc.

Greene, William H. 2003. Econometric analysis. 5th edition. Upper Saddle River, NJ: Prentice-Hall.

Grossman, Michael, Frank J. Chaloupka, and Ismail Sirtalan. 1998. An empirical analysis of alcohol addiction: Results from the Monitoring the Future panels. Economic Inquiry 36:39-48.

Grossman, Michael, Robert Kaestner, and Sara Markowitz. 2002. Get high and get stupid: The effect of alcohol and marijuana use on teen sexual behavior. National Bureau of Economic Research Working Paper No. 9216.

Gruber, Jonathon. 2001. Introduction. In Risky behavior among youths, edited by Jonathon Gruber. Chicago: University of Chicago Press, pp. 1-28.

Gruenewald, P. J., W. R. Ponicki, and H. D. Holder. 1993. The relationship of outlet densities to alcohol consumption: A time series cross-sectional analysis. Alcoholism: Clinical and Experimental Research 17:38-47.

Kenkel, Donald S. 1993. Drinking, driving and deterrence: The effectiveness and social costs of alternative policies. Journal of Law and Economics 36:861-76.

Kubik, Jeffrey D., and John R. Moran. 2003. Can policy changes be treated as natural experiments? Evidence from state excise taxes. Working Paper, Department of Economics, Syracuse University.

Leung, S. F., and C. E. Phelps. 1993. "My kingdom for a drink ... ?": A review of estimates of the price sensitivity of demand for alcoholic beverages. In Economics and the prevention of alcohol-related problems: Proceedings of a workshop on economic and socioeconomic issues in the prevention of alcohol-related problems, October 10-11, 1991, edited by M. E. Hilton and G. Bloss. Bethesda, MD: NIAAA Research Monograph No. 25:1-31.

Manning, Willard G., Linda Blumberg, and Lawrence H. Moulton. 1995. The demand for alcohol: The differential response to price. Journal of Health Economics 14:123-48.

$\rightarrow$ Markowitz, Sara. 2000. The price of alcohol, wife abuse, and husband abuse. Southern Economic Journal 67:279-303.

Markowitz, S., P. Chatterji, R. Kaestner, and D. Dave. 2002. Substance use and suicidal behaviors among young adults. NBER Working Paper No. 8810.

$\rightarrow$ Mast, Brent D., Bruce L. Benson, and David W. Rasmussen. 1999. Beer taxation and alcohol-related fatalities. Southern Economic Journal 66:214-49. 
Nelson, J. P. 1997. Economic and demographic factors in U.S. alcohol demand: A growth accounting analysis. Empirical Economics 22:83-102.

Nelson, J. P. 2003. Advertising bans, monopoly, and alcohol demand: Testing for substitution effects using state panel data. Review of Industrial Organization 22:1-25.

Nephew, T. M., G. D. Williams, H. Yi, A. K. Hoy, F. S. Stinson, and M. C. Dufour. 2002. NHTSA surveillance report \#59: Apparent per capita alcohol consumption: National, state, and regional trends, 1970-99. Rockville, MD: National Institute on Alcohol Abuse and Alcoholism, Division of Biometry and Epidemiology.

Quinn, Bernard, Herman Anderson, Martin Bradley, Paul Goetting, and Peggy Shriver. 1980. Churches and church membership in the United States 1980. Atlanta: Glenmary Research Center.

Ruhm, C. 1996. Alcohol policies and highway vehicle fatalities. Journal of Health Economics 15:435-54.

Sloan, F. A., B. A. Reilly, and C. M. Schenzler. 1994. Effects of prices, civil and criminal sanctions, and law enforcement on alcohol-related mortality. Journal of Studies on Alcohol July: 454-65.

U.S. Bureau of the Census. Tourism data from US Bureau of Economic Analysis. Available http://www.bea.doc.gov/bea/ regional/gsp/. Accessed 24 October 2005.

Wagenaar, Alexander C. Alcohol Epidemiology Program, University of Minnesota, School of Public Health.

Young, D. J., and A. Bielinska-Kwapisz. 2002. Alcohol taxes and beverage prices. National Tax Journal LV:57-73.

Young, D. J., and A. Bielinska-Kwapisz. 2003. Alcohol consumption, beverage prices, and measurement error. Journal of Studies on Alcohol 64:235-238.

Young, D. J., and T. W. Likens. 2000. Alcohol regulation and auto fatalities. International Review of Law and Economics 20:107-26 